Proc. of the Third Intl. Conf. on Advances in Management, Economics and Social Science - MES 2015.

Copyright $($ Institute of Research Engineers and Doctors, USA .All rights reserved.

ISBN: 978-1-63248-081-1 doi: 10.15224/ 978-1-63248-081-1-123

\title{
Relationship between the Climate changes and Human adaptive strategies in Sri Lanka with special reference to Puttlam District
}

\subsection{Introduction to the Research}

The principle objective of my research is to examine the relationship between the Climate changes and the Human adaptive strategies in Sri Lanka with special reference to Puttlam district in 1980s to contemporary period. Studying the climate changes in Sri Lanka can be identified, previous 40 years of period main component of climate has been changed. When considering the rainfall it could be identified seasonal rainfall has been transform and also temperature. Annual rainfall in Sri lanka has not be change dramatically but studying the last 40 years type of rain is in extreme levels. So that droughts and flood were occurred regarding that extreme climate changes.

So that the area called Puttlam is situated in Dry zone has to face natural hazards. Specially I paid my attention to Anamaduwa GN division to identify the adaptive strategies of human, because this area can be categorized the one of poorest areas and also marginalized area in Sri Lanka (according to census and statistics in Sri Lanka).

However these extremist situation (climate changes and environmental hazard) the people those who are living in this area has no enthusiastic to migrate for other areas. They can't cultivate that what they want and also people are in under development but they loved and adaptive for the environment. In my research I try to identify the socio- economic, cultural ecological and political ecological factors that underlying this adaptation and I'd try to make a conceptual framework on that regards. 
Proc. of the Third Intl. Conf. on Advances in Management, Economics and Social Science - MES 2015.

Copyright $($ Institute of Research Engineers and Doctors, USA .All rights reserved.

ISBN: 978-1-63248-081-1 doi: 10.15224/ 978-1-63248-081-1-123

\subsection{Research Problem}

What are the adaptive strategies that human use for the changes of climate?

\subsection{Study Area}

Puttlam is a district situated near to the West coast of Sri Lanka.It has an area of 2,976 km2 (1149 sqmi).It formulated the North western province of Sri Lanka (Map No: 01).It is disseminated by climatology classification as a Dry Zone because of variety of climate, Landscape and forest types. Temperature of this district is considered relatively along with the rainfall it is follows,

Table No: $01 \quad$ Annual Rainfall and Temperature in Puttlam District

\begin{tabular}{|l|r|r|r|r|}
\hline Name of DSD & Sq K.m. & $\begin{array}{l}\text { Inland water } \\
\text { Area Hec. }\end{array}$ & $\begin{array}{l}\text { Annual } \\
\text { Temperature C }\end{array}$ & Annual Rainfall m.m. $^{\mathbf{}}$ \\
\hline Anamaduwa & 134 & 1630 & 31.1 & 1299 \\
\hline Arachchikattuwa & 72 & 1200 & 24.5 & 1521 \\
\hline Dankotuwa & 74.6 & 40.2 & 22.2 & 1582.4 \\
\hline Chilaw & 91 & 1635 & 32.8 & 1676.5 \\
\hline Kalpitiya & 94.3 & 46.7 & 29.2 & 662.6 \\
\hline Karuwalagaswewa & 490.4 & 450 & 28.2 & 903 \\
\hline Madampe & 91.1 & 183 & 27.8 & 1450.7 \\
\hline Mahakubukkadawala & 107.2 & 1162.9 & 26 & 52.4 \\
\hline Mahawewa & 96.3 & 2020 & 25.6 & 1451 \\
\hline Mundalama & 202.5 & 320.6 & 31.4 & 1521 \\
\hline Naththandiya & 71.9 & 181.2 & 27.3 & 1384 \\
\hline Nawagaththegama & 163.7 & 690 & 31.2 & 1227 \\
\hline Pallama & 120.5 & 250.5 & 29 & 1303.8 \\
\hline Puttlam & 113.6 & 981 & 27.7 & 818.3 \\
\hline Wanathwilluwa & 710.4 & 304 & 30.2 & 1060 \\
\hline Wennappuwa & 24 & 148.4 & 27.4 & 1384 \\
\hline Source: Sampath Pathikda, Divisional Secretariat of Puttlam, 2013 & & & \\
\hline
\end{tabular}

Puttlam Could be reckoned as an area the minimum annual rainfall $52 \mathrm{~m} . \mathrm{m}$. which rises up to $1700 \mathrm{~m} . \mathrm{m}$. and generally the area is treated as a dry region. The rainfall figures for all DSDs in the area indicate that the average, at least less than 2000 m.m. The average temperature exists from $22 \mathrm{C}^{0}$ to $32 \mathrm{C}^{0}$. This area could be treated as a region which a high priority is given to length of droughts.

The extent of internal water ways is 11243.5 hectares. The water is mostly salty and it is very difficult to carry out paddy cultivation from rain water. The area is cultivated from water 
Proc. of the Third Intl. Conf. on Advances in Management, Economics and Social Science - MES 2015.

Copyright (C) Institute of Research Engineers and Doctors, USA .All rights reserved.

ISBN: 978-1-63248-081-1 doi: 10.15224/ 978-1-63248-081-1-123

provided by major and minor irrigational projects. Paddy and coconuts plantations are the key crops in the district. In relation to the other parts of Sri Lanka, the extend of land in this area is limited.

Table No:02 The extent of Land available for paddy cultivation in Puttlam district

\begin{tabular}{|c|c|c|c|c|}
\hline Name of DSD & Major Irrigation & Minor Irrigation & Rain water & Total \\
\hline Anamaduwa & 1593.6 & 5580.2 & 359.6 & 7533.4 \\
\hline Arachchikattuwa & 823 & 874 & 222 & 1919 \\
\hline Dankotuwa & $\mathbf{0}$ & 2119.2 & $\mathbf{0}$ & 2119.2 \\
\hline Chilaw & 1428.6 & 1153.2 & 911.4 & 3493.2 \\
\hline Kalpitiya & $\mathbf{0}$ & $\mathbf{0}$ & $\mathbf{0}$ & $\mathbf{0}$ \\
\hline Karuwalagaswewa & 6350 & 5038 & 86.4 & 11474.4 \\
\hline Madampe & 217.75 & 427.2 & 194.6 & 839.4 \\
\hline Mahakubukkadawala & 899 & 1399.8 & 187 & 2485.8 \\
\hline Mahawewa & 143 & 1171 & 57 & 1371 \\
\hline Mundalama & 123 & 874 & 222 & 1219 \\
\hline Naththandiya & 1111.5 & 6972.8 & 506.3 & 8590.6 \\
\hline Nawagaththegama & 819.5 & 7928 & 4974 & 21097 \\
\hline Pallama & $\mathbf{0}$ & 5742 & 913.6 & 6655.6 \\
\hline Puttlam & 511 & 667 & 99 & 1277 \\
\hline Wanathwilluwa & 1074 & 237 & 4.9 & 1315.9 \\
\hline Wennappuwa & $\mathbf{0}$ & 6.9 & 0.4 & 7.3 \\
\hline Total & 22469.45 & 40190.27 & 8738.16 & 71397.88 \\
\hline
\end{tabular}

As this situation is very unfavorable for agriculture, people of the area have taken to livestock farming.

Table No: 03 Livestock Farming in Puttlam district

\begin{tabular}{|c|c|c|c|c|}
\hline Name of DSD & Hens & Pigs & Goats & Cow \\
\hline Anamaduwa & 31600 & 720 & 3100 & 10950 \\
\hline Arachchikattuwa & 280300 & 6250 & 24050 & 11500 \\
\hline Dankotuwa & 62090 & 320 & 273 & 2082 \\
\hline Chilaw & 120000 & 2400 & 1000 & 4682 \\
\hline Kalpitiya & 8058 & 868 & 1241 & 673 \\
\hline Karuwalagaswewa & 22349 & 966 & 2290 & 8000 \\
\hline Madampe & 56000 & 3056 & 278 & 30080 \\
\hline Mahakubukkadawala & 32003 & 1095 & 3796 & 7640 \\
\hline Mahawewa & 74250 & 2324 & 2232 & 2420 \\
\hline Mundalama & 280300 & 6250 & 24050 & 11500 \\
\hline
\end{tabular}


Proc. of the Third Intl. Conf. on Advances in Management, Economics and Social Science - MES 2015.

Copyright (C) Institute of Research Engineers and Doctors, USA .All rights reserved.

ISBN: 978-1-63248-081-1 doi: 10.15224/ 978-1-63248-081-1-123

\begin{tabular}{|c|c|c|c|c|}
\hline Naththandiya & 900300 & 6185 & 910735 & 300 \\
\hline Nawagaththegama & 3560 & 235 & 125 & 2350 \\
\hline Pallama & 73400 & 1000 & 2100 & 7665 \\
\hline Puttlam & 27550 & 5042 & 2550 & 6749 \\
\hline Wanathwilluwa & 2537 & 650 & 1325 & 2810 \\
\hline Wennappuwa & 55000 & 1500 & 500 & 1000 \\
\hline Total & 2029297 & 38861 & 979645 & 110401 \\
\hline
\end{tabular}

The geological structure represents a complex of Miocene limestone. The Jaffna Peninsula and surrounding island in the extreme north and the north- western coastal strip extending to Puttlam are underlain by the mannar Sandstone and the Vanathawillu limestone of Miocene age. The latter is mostly a partly crystalline, indistinctly bedded, creamy coloured rock, richly fossiliferous in parts and mostly flat- bedded.As regards the soil structure of the area, it could be abundantly seen that Red yellow latosols, Regosols, Alluvial soil and Solodized solonetz soil is available (Kure,2003). Also the soil medium, being a dry paste of soils. This Alluvial soil intergrated with quality of bed rocks. Therefore, genaraly the grasses or the holomorphic plants cover the area.

Map No: 01 Study Area

\section{Puttlam District}

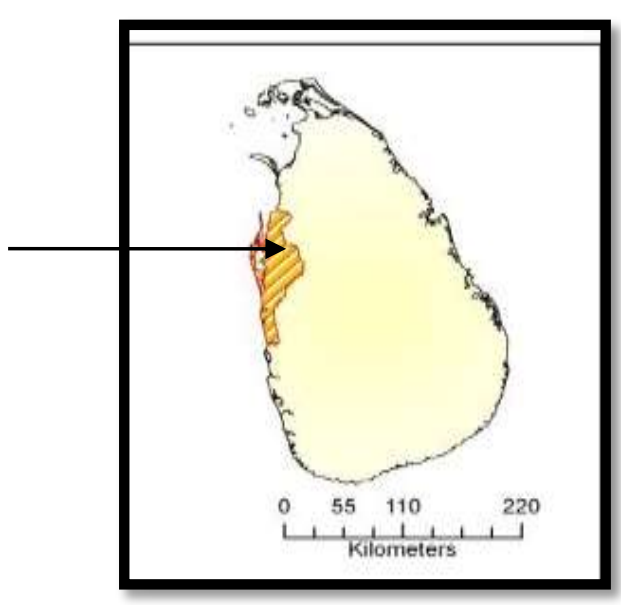

\subsection{Research Methodology}

In this research has equal impotence of both primary and secondary data. I am try to understand the climate changes in entire Sri Lanka through the secondary date that were collected by the Meteological Department in Sri Lanka. In order to examine the patterns of climate changes, 1980 to 2015 monthly and 
Proc. of the Third Intl. Conf. on Advances in Management, Economics and Social Science - MES 2015.

Copyright (C) Institute of Research Engineers and Doctors, USA .All rights reserved.

ISBN: 978-1-63248-081-1 doi: 10.15224/ 978-1-63248-081-1-123

annual rainfall and temperature data will be map using the geographical information system called SP Line. Instead one division, Puttlam district select to the micro scale study.

In the other hand the study of relationship between climate changes and adoptive strategies of human is a physical and Socio- economical geographic factor analysis. Majority of the objective of the research cannot be comprehended and explain using by statistical methods. A qualitative data collection like case studies and life history methods will be restricted explanatory prospects in such situation. Based on that, I hope to collect the primary data through case studies as deep interview and genealogical studies. 